\title{
TECHNOLOGY UPGRADING AND GROWTH IN CENTRAL AND EASTERN EUROPE
}

\author{
Slavo Radosevic ${ }^{1}$, Deniz E. Yoruk ${ }^{2}$ and Esin Yoruk $^{3}$ \\ This is pre-print version of Chapter 8 in volume \\ 'Social and Economic Development in Central and Eastern Europe: Stability and Change after \\ $1990 "$ \\ Routledge, forthcoming 2019 \\ Editor: Grzegorz Gorzelak
}

\begin{abstract}
The R\&D and technology issues of relevance for catching up cannot be understood or conceptualised only within the R\&D based growth model. With this motivation in mind, we have created a composite indicator of innovation capacity and performance of the CEECs, as well as of the EU25, which is meaningful from the perspective of countries lagging behind the world technology frontier. Three conclusions stem from the Index of Technology Upgrading components which have major relevance for policy making. Firstly, we observe a decline in most of the EU25 economies of their production capabilities despite, on average, significant improvements in R\&D and technology capability. This suggests that the EU has serious weaknesses in converting its R\&D and technological knowledge into production capabilities. Secondly, the Index of Technology Upgrading components show improvements in infrastructure and structural changes in most of the EU economies, but an overall relative decline in firm capabilities. This shows the limitations of current EU supply oriented RDI policies which continue to reinforce the so-called European paradox. Thirdly, increased knowledge interaction between 2006 and 2015 has been confined to the German-led Central European manufacturing cluster. It seems that the EU RDI policy operates as a substitute for technology and knowledge exchange rather than as a complement to it.
\end{abstract}

\footnotetext{
${ }^{1}$ University College London

${ }^{2}$ Coventry University

${ }^{3}$ Aston Business School
} 


\section{Introduction}

The economies of Central and Eastern Europe (CEE) grew rapidly at the beginning of the $21^{\text {st }}$ century until the 2008 global financial crisis, which hit this region very badly, with some exceptions (e.g. Poland). Since 2008 growth has resumed, but at much lower levels and the process of convergence, that was very strong before 2008 , has slowed down substantially. This raises issues about the foundations of the pre-2008 growth, as well as the basis of future long-term growth.

With the benefit of hindsight, pre-2008 growth in CEE could be characterised as financedependent and debt-intensive growth, based on externally financed consumption (consumer durables) (in most of the CEECs) (Labaye et al., 2013). The post-2008 challenge is how to shift towards growth driven by investments and improvements in productivity. The issue of the basis of growth is quite important, as growth before 2008 was driven by total factor productivity, or what is conventionally defined as technological progress, or by improvements in efficiency. ${ }^{4}$ Moreover, labour productivity in CEECs was visibly higher before 2008 when compared to the recent period. On average, after 2008 we observe weak convergence between CEE and old member states, but this de facto is hiding a pattern of polarisation within both old EU15 and CEECs. This suggests that drivers of growth or decline have become more diverse within the EU, which as a region has shown declining growth dynamics from the early 2000 s.

We consider the technology upgrading approach to be relevant for monitoring technology upgrading in catching-up economies like CEECs. Gereffi (1999: 51-2) defines it as "a process of improving the ability of a firm or an economy to move to more profitable and/or technologically sophisticated capital and skill-intensive economic niches". Technology upgrading is 'a shift to higher value-added products and production stages through increasing specialization'.

In addition, the technology upgrading framework shows what is behind the lack of convergence in technology and innovation capability, and the very weak dynamics, of the EU25. ${ }^{5}$ First, we point to the disjunction between production capability, and R\&D and technological capability. We consider this to be a direct effect of EU policy, which favours $R \& D$ but does relatively less to support production capability and innovation implementation. Second, the lack of progress in capabilities in the EU is striking in relation to the strong policy drive and improvements regarding S\&T and innovation infrastructure which suggest that there is a disjunction between $\mathrm{RD} /$ innovation and industrial policy in the EU. Finally, we show that the intensity of knowledge exchange in the EU25 is unrelated to technology upgrading and structural changes, except possibly for the German led Central European manufacturing cluster. This suggests that there is a disjunction between FDI/value chains policy and national and EU level innovation policies. In summary, we show that the monitoring framework, which is conceptually grounded in the literature on technology accumulation and catch-up, can generate very relevant policy insights.

\footnotetext{
${ }^{4}$ For evidence see Dobrinsky, R., D. Hesse and R. Traeger (2006) and Alam et al. (2008).

${ }^{5}$ Our analysis is confined to EU economies with the exception of Malta, Cyprus and Luxembourg which are economies with either quite specific economic structure or size which would not add qualitatively new insights to our analysis.
} 
This chapter is organised as follows: first, we explain the differences between the R\&D driven approach to growth and indexes of technology upgrading conceptualised in a more comprehensive setting. Second, we rank EU economies based on our indexes. We present the main results of analysis based on indexes of technology upgrading and conduct a descriptive analysis of each of the three sub-indexes of technology upgrading which point to the three major insights outlined above. We further elaborate on sub-indexes of the main indexes to compare macro-regions of CEE with other macro regions of the EU in the north and south. We conclude by drawing policy challenges that our analysis has generated.

\section{The narrow (R\&D) and broad (ITU) approach to assessing technology accumulation in CEE}

Metrices of innovation dynamics explicitly or implicitly assume a specific understanding on how technology and innovation impacts growth. For example, a conventional policy model of technology upgrading assumes that R\&D is the major source of growth. This model is the basis of the new (endogenous) growth theory (Romer, 1990; Lucas, 1988). Endogenous growth models assume that $R \& D$ is essentially a probabilistic process with a partly public nature, and thus brings technology spillovers which in turn lead to increasing returns to scale. A strong focus in innovation metrices on $R \& D$ reflects the generally accepted view that R\&D and innovation are among the main drivers of sustained economic growth. ${ }^{6}$ However, the linear logic by which more R\&D should lead to more economic growth is a somewhat simplified picture of reality. Innovation literature does not actually support such a narrow approach to the relationship between innovation and growth. Ultimately, an extensive literature on innovation systems has emerged as counterevidence to the simplified view that R\&D suffices for innovation and growth. This literature, as well as the Schumpeterian growth theory, have shown that R\&D does not play an identical role in economies at different levels of development. For example, middle-income economies tend to grow more on imitation activities, while transition towards the high-income group requires a shift towards technology frontier activities, where R\&D plays a more important role (see Aghion et al., 2013; Aghion et al., 2010). For example, this has been recognised by the WEF Global Competiveness Reports which classifies CEECs in terms of driving factors of growth as: Efficiency driven (BLG/ROU); in transition (other CEECs), and Innovation-driven (SVN, EST).

Our approach is based on the premise that the CEE countries are predominantly technology users; however, the pattern of their technology upgrading is different, and thus they require appropriately amended metrics.

\subsection{R\&D investments and outputs in Central and Eastern Europe}

\footnotetext{
${ }^{6}$ For example, the OECD Growth Study (OECD, 2003) has identified a clear positive linkage between private sector R\&D intensity and growth in per capita gross domestic product (GDP) for OECD economies. The analysis could find no clear-cut relationship between public R\&D activities and growth, at least in the short term.
} 
After the 'transition recession' during the 1990s, R\&D systems in CEE started to recover during the first decade of the $21^{\text {st }}$ century. GERD/GDP ratios for EU_CEECs increased from below $0.8 \%$ until 2006 to $1.16 \%$ in 2012 or by 0.4 percentage points of GDP. It is important to recognise that on average GERD/GDP did not increase during the period of economic growth or before 2008, but only after 2008 when GDP had fallen in many CEECs. This increase was very strong in all new member states (NMS) except Croatia, where GERD/GDP fell from $0.95 \%$ (2002) to $0.75 \%$ (2012) of GDP and Romania where the fall was from $0.58 \%$ (in 2008) to $0.48 \%$ (in 2012). The picture after 2012 until 2016 is somewhat mixed, with some countries experiencing a continuing increase, while some others a decrease in their GERD/GDP. The clear fact is that, in 2016, all countries showed a considerable decline in their GERD /GDP, except Croatia which demonstrated a relatively constant share of GERD in their GDP ranging between $0.74-0.85$ in the preceding ten years.

Table 1. Gross domestic expenditures on R\&D in GDP (GERD/GDP) in CEECs

\begin{tabular}{|c|c|c|c|c|c|c|c|c|c|c|c|c|c|c|c|}
\hline & 2002 & 2003 & 2004 & 2005 & 2006 & 2007 & 2008 & 2009 & 2010 & 2011 & 2012 & 2013 & 2014 & 2015 & 2016 \\
\hline Slovenia & 1.44 & 1.25 & 1.37 & 1.41 & 1.53 & 1.42 & 1.63 & 1.82 & 2.06 & 2.42 & 2.57 & 2.58 & 2.37 & 2.2 & 2 \\
\hline Czechia & 1.1 & 1.15 & 1.15 & 1.17 & 1.23 & 1.3 & 1.24 & 1.29 & 1.34 & 1.56 & 1.78 & 1.9 & 1.97 & 1.93 & 1.68 \\
\hline Estonia & 0.72 & 0.77 & 0.85 & 0.92 & 1.12 & 1.07 & 1.26 & 1.4 & 1.58 & 2.31 & 2.12 & 1.72 & 1.45 & 1.49 & 1.28 \\
\hline Hungary & 0.98 & 0.92 & 0.86 & 0.92 & 0.98 & 0.96 & 0.98 & 1.13 & 1.14 & 1.19 & 1.26 & 1.39 & 1.35 & 1.36 & 1.21 \\
\hline Poland & 0.56 & 0.54 & 0.55 & 0.56 & 0.55 & 0.56 & 0.6 & 0.66 & 0.72 & 0.75 & 0.88 & 0.87 & 0.94 & 1 & 0.97 \\
\hline Croatia & 0.95 & 0.95 & 1.03 & 0.86 & 0.74 & 0.79 & 0.88 & 0.84 & 0.74 & 0.75 & 0.75 & 0.81 & 0.78 & 0.84 & 0.85 \\
\hline Lithuania & 0.66 & 0.66 & 0.75 & 0.75 & 0.79 & 0.8 & 0.79 & 0.83 & 0.78 & 0.9 & 0.89 & 0.95 & 1.03 & 1.04 & 0.85 \\
\hline Slovakia & 0.56 & 0.56 & 0.5 & 0.49 & 0.48 & 0.45 & 0.46 & 0.47 & 0.62 & 0.66 & 0.8 & 0.82 & 0.88 & 1.18 & 0.79 \\
\hline Bulgaria & 0.47 & 0.48 & 0.47 & 0.45 & 0.45 & 0.43 & 0.45 & 0.49 & 0.56 & 0.53 & 0.6 & 0.63 & 0.79 & 0.96 & 0.78 \\
\hline Romania & 0.38 & 0.38 & 0.38 & 0.41 & 0.45 & 0.51 & 0.55 & 0.45 & 0.46 & 0.5 & 0.48 & 0.39 & 0.38 & 0.49 & 0.48 \\
\hline Latvia & 0.41 & 0.36 & 0.4 & 0.53 & 0.65 & 0.55 & 0.58 & 0.45 & 0.61 & 0.7 & 0.66 & 0.61 & 0.69 & 0.63 & 0.44 \\
\hline EU CEE & 0.75 & 0.73 & 0.76 & 0.77 & 0.82 & 0.80 & 0.86 & 0.89 & 0.96 & 1.12 & 1.16 & 1.15 & 1.15 & 1.19 & 1.03 \\
\hline
\end{tabular}

Source: Eurostat

Table 1 shows that increases of GERD/GDP in Slovenia, Czechia, Estonia and Hungary have been quite dramatic or well above the regional average increase of 0.4 percentage points. In the first three countries, increases have been around 0.6 percentage points of GDP. In other CEE countries these increases ranged between 0.2 and 0.4 percentage points (see Figure 1 ).

Figure 1. Changes in shares of GERD/GDP in percentage points of GDP 2002-2016

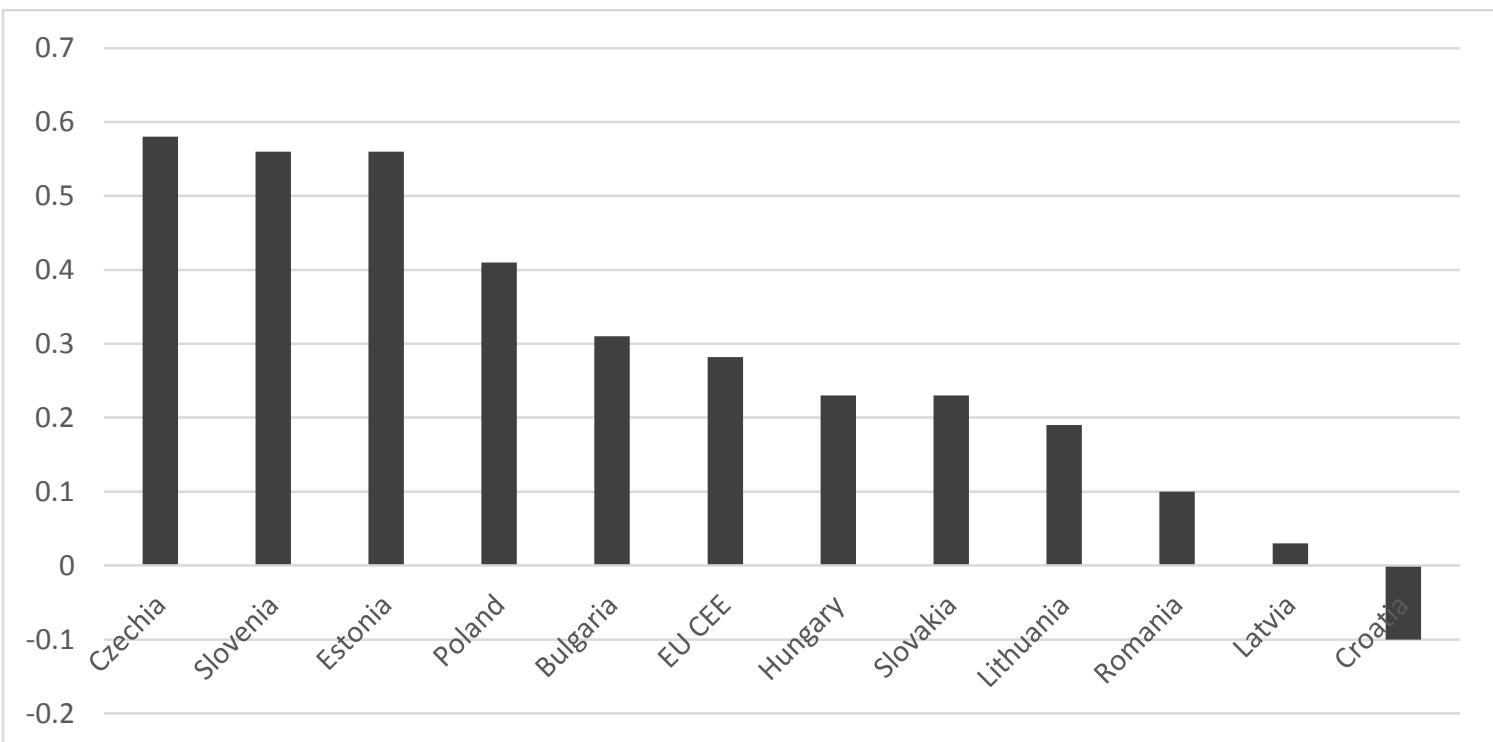

Source: Calculations based on Table 1. 
Where do changes in the CEE GERD/GDP funding stand in the broader EU context? Figure 2 shows that changes in CEE are within the EU28 range. The most significant improvements in R\&D intensity among the EU28 countries have taken place in Austria, followed by Belgium, Czechia, Estonia, Slovenia, Portugal and Germany. Other CEE countries are scattered across the EU28 spectrum including countries with relative declines in R\&D intensity (Croatia with Finland and Iceland) or marginal increases (Romania with France and the UK).

Figure 2. Changes in GERD/GDP ratios in percentage points between 2002-2016 and 20082016.

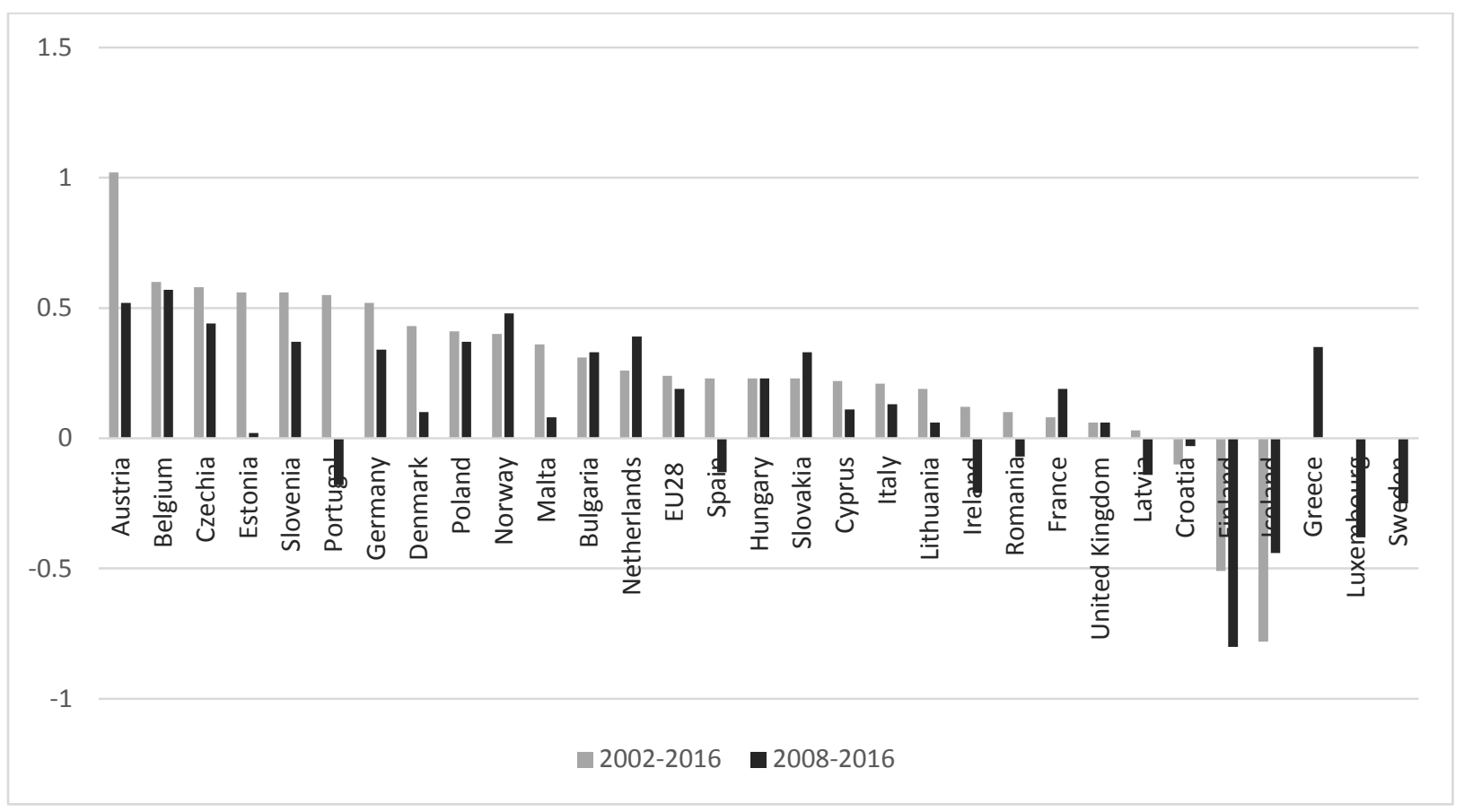

Source: Authors' calculations based on Eurostat

Changes in the 2002-2016 period show very strong effects of the 2008 crisis until 2012, with a turnaround from 2012 to 2016 . More precisely, they show quite a different role of R\&D which was used either as an anti-cyclical instrument to stimulate demand for technology, or as expenditure that shared the impact of austerity policies targeting not directly productive expenses.

In this respect, in Austria, Belgium, Czechia, Slovenia, Germany, Poland, Norway, Bulgaria, the Netherlands, Hungary, Slovakia and Greece, R\&D expenditures were anti-cyclical while in Portugal, Spain, Ireland, Latvia, Croatia, Finland, Iceland, Luxembourg and Sweden, R\&D was pro-cyclical.

This brief analysis suggests that despite the 2008 crisis, investment in R\&D in CEE increased until 2012, after which CEE countries, except Poland, Bulgaria and Croatia, have shown declining investment in R\&D. We presume that the increases in CEE after 2008 are largely due to the EU support for R\&D and innovation through Structural Funds. Moreover, the increase in R\&D investments in all CEE countries in this period (2008-2012) outperformed 
the decrease in the 2012-2016 period (except Latvia). In this respect, EU funds play a very important counter-cyclical role in preventing the further decline of GDP.

\subsection{Growth in GNI and GNI per capita in CEE}

Growth rates were severly hampered throughout the EU after the 2008 crisis (see Figures 3 and 4). After 2008 CEE grew at slightly higher rates than the EU North and EU South. However, the considerably high growth rates achieved by the CEE during the 2002-2016 period is at odds with the very low level of R\&D expenditures in CEE. In particular, the high growth rates attained by Romania and Bulgaria cannot be linked to R\&D investments. We need a perspective which is broader than R\&D and which can capture the diversity of technology efforts that have been taking place in catching-up economies. R\&D is an important, but is far from sufficient metric. This simple observation has led us to the construction of technology upgrading indexes which capture production capabilities as well as innovative capabilities, structural issues underlying the growth process and also global knowledge interactions taking place to contribute to further growth.

Figure 3. GNI growth rate in the EU countries, 2002-16 and 2008-16 (\%) (Atlas method, current USD). 


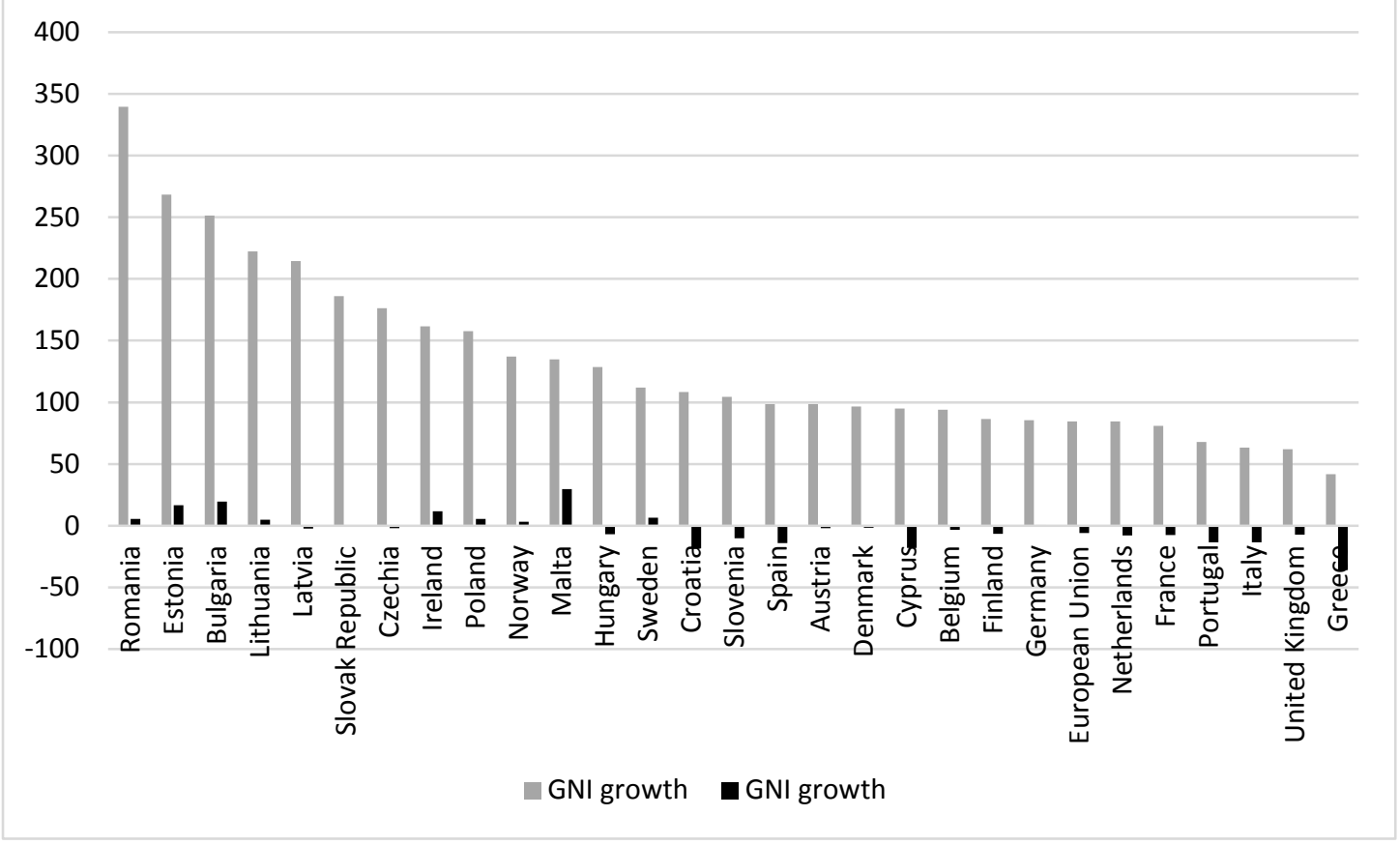

Source: World Bank, World Development Indicators

Figure 4. GNI per capita growth rate in the EU countries, 2002-16 and 2008-16 (\%) (Atlas method, current USD).

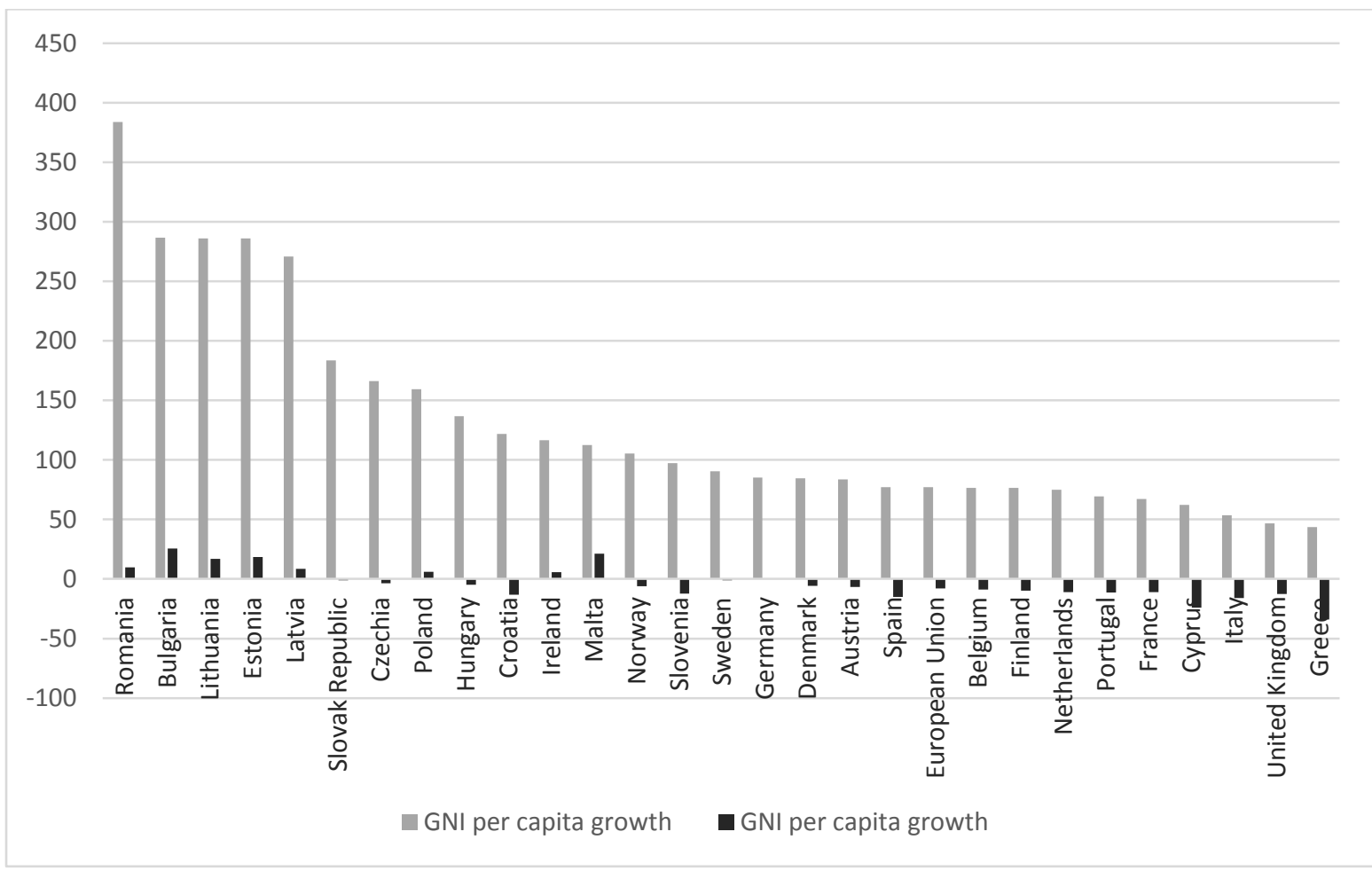

Source: World Bank, World Development Indicators

2.3 A comprehensive view on technology and growth in CEE: Indexes of technology upgrading 
Why do we need an industrial/ technological upgrading perspective? The underlying idea behind this approach is that growth is not solely driven by investment in R\&D and knowledge. Capital accumulation is also important, but it should contain a large learning or assimilation of technological knowledge component. Technology upgrading denotes substantial changes in a country's specialisation and knowledge base that increase its capacity for value generation (Ernst 1998). This process is the outcome of interactions of 'a set of institutions, incentives and policies that can mobilize huge savings and put them to productive use, while at the same time promoting learning efficiency and a broad domestic knowledge base' (Ernst, 1998). Gereffi (1999: 51-2) defines it as "a process of improving the ability of a firm or an economy to move to more profitable and/or technologically sophisticated capital and skill-intensive economic niches". Technology upgrading is 'a shift to higher value-added products and production stages through increasing specialization'. However, while being very relevant, this approach is still underdeveloped in terms of economic theory. For the time being, there is no theory of industrial/ technological upgrading but only a few vague stylisations. In Radosevic and Yoruk $(2015,2016 a)$ we review the literature on this area and develop a conceptual approach, which is then applied in Radosevic and Yoruk (2016b).

The underlying idea behind the technology upgrading approach is the importance of structural differences between low, middle and high-income EU countries. In this respect, our approach is in line with the ideas of new structural economics (Lin, 2015) and Schumpeterian economics (Lee, 2013; Aghion et al, 2013). Our analysis in this chapter should answer an important policy question in the EU context: what is the position of CEECs in the context of Industrial and Technology Upgrading within the wider Europe?

A theoretical and conceptual basis of the new metrics is developed in Radosevic and Yoruk (2016). It conceptualizes technology upgrading as a three dimensional process composed of: intensity and different types of technology upgrading through various innovation and technology activities; broadening of technology upgrading through different forms of technology and knowledge diversification; and interaction with the global economy through knowledge import, adoption and exchange. All three dimensions have strong grounding in the respective literatures on firm level technology upgrading, structural change and growth, and integration in the global economy.

The index of technology upgrading is conceptually based on two dimensions, the intensity of technology upgrading (Index A) and the breadth or structural features of technology upgrading (Index $B$ ), which jointly form the index. A third dimension is the index of technology and knowledge exchange (Index $\mathrm{C}$ ) which is a proxy for interaction with the global economy; it does not form part of the overall index but operates as separate index and helps us to understand how economies go about this third dimension of technology upgrading. Index $C$ interacts with the index of technology upgrading (Indexes A and B) but does not directly contribute to it (see Table 2). The reasons for this are related to the varying role - complementary or substitutive - that technology and knowledge exchange can play in relation to domestic technological activities, which are the primary drivers of technology upgrading. 
The data are classified into two main categories and six components of the technology upgrading framework to create an index of technology upgrading (ITU). We generate a separate index for the technology and knowledge exchange element (ITKE) (see Table 2).

Table 2. Indexes of technology upgrading

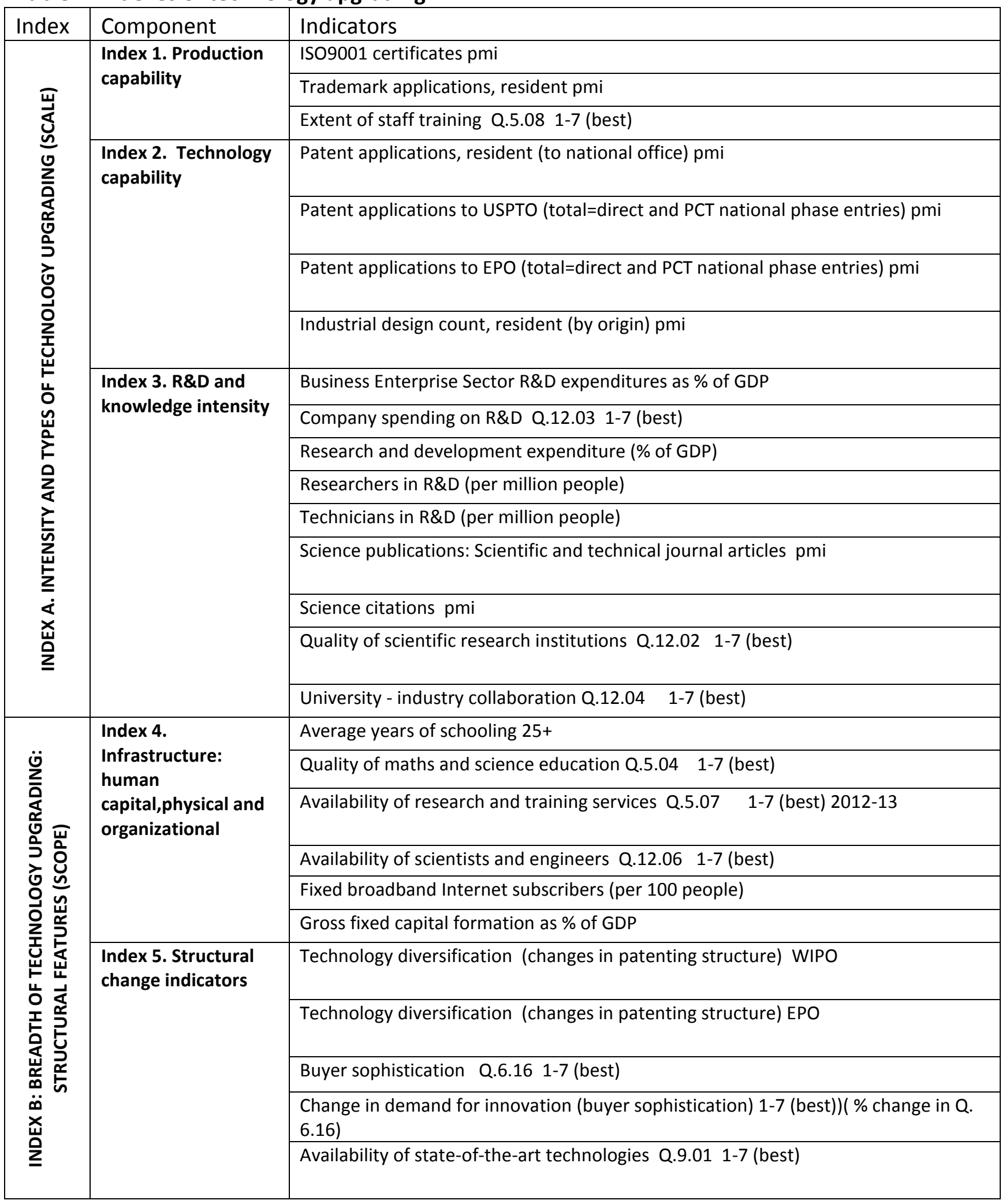




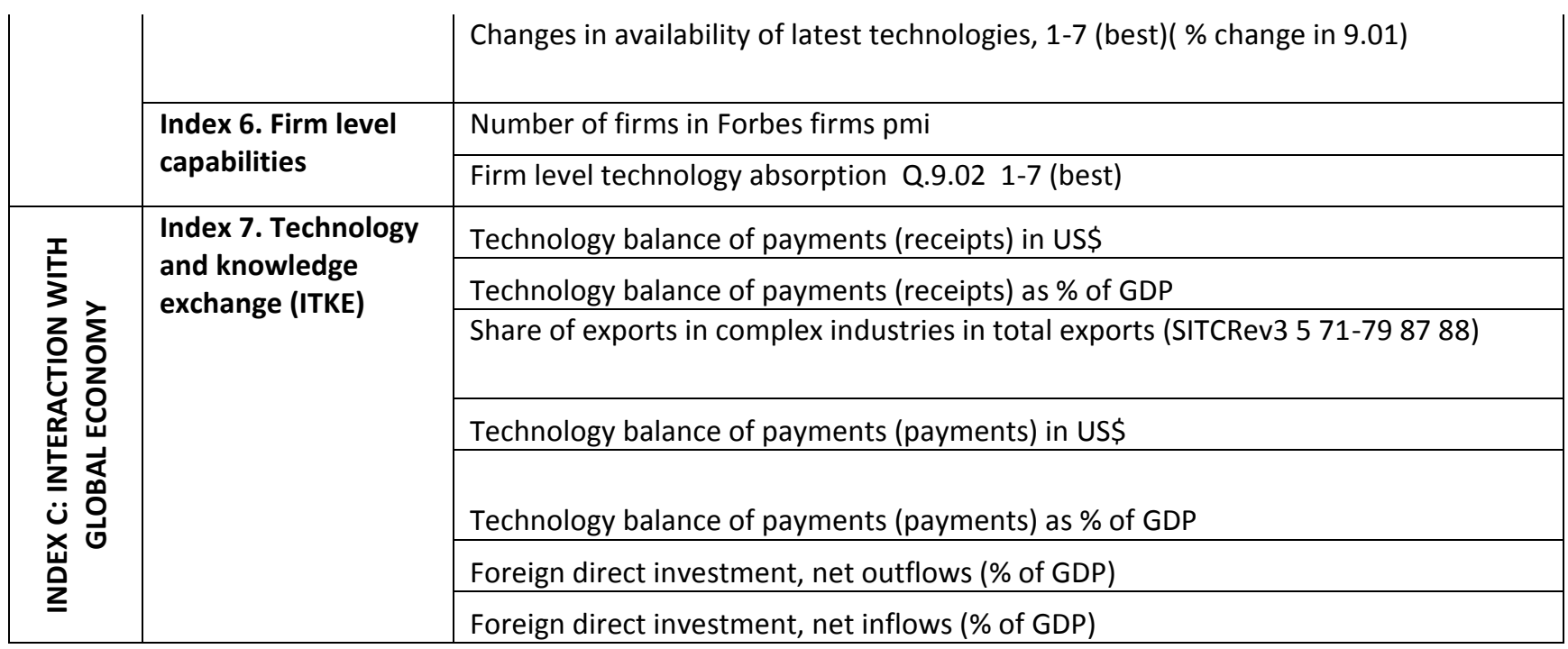

Source: Radosevic and Yoruk (2015, 2016a, 2016b, 2018)

Radosevic and Yoruk (2015) applied a new metrics of technology upgrading to CEECs on a sample of 42 economies ranging from lower middle income to upper high income level economies. The index of technology upgrading represents a proxy of potential for technology upgrading., A situation where a country has a low income per capita but a high index of technology upgrading suggests that this country has good potential for growth based on technology upgrading. Meanwhile, a country that currently enjoys high growth rates but performs poorly on the index of technology ugrading is likely to face limits to further long-term growth. Radosevic and Yoruk (2018) have explored this issue in the context of the middle income gap, with specific focus on different income levels. In this chapter, we use anidentical approach and estimation methodology with the aim of exploring the issues of technology catch-up in the EU28. We follow a standard composite indicators methodology for ITU indexes which we summarise in the Appendix.

\section{Indexes of technology upgrading}

Table 3 illustrates our technology upgrading index measures and the percentage change in the main index ITU from 2006 to 2015, as congregated into 5 major group of countries in the EU. Leading group is 10 developed economies which we label as 'North' group (Sweden, Finland, Denmark, Germany, Netherlands, France, UK, Ireland, Belgium and Austria). There is a significant gap between this and the second group which is somewhat less homogenous and forms the EU 'periphery', consisting of the EU South (Portugal, Italy, Spain, Greece) and EU East (Baltic states3, Visegrad 5 - Czechia, Slovakia, Poland, Hungary, Slovenia, and SouthEast 3 - Bulgaria, Romania and Croatia). These two groups remain identical between 2006 and 2015, showing that the technology gap has not been closed by any of the periphery economies. Moreover, the upper periphery groups remain composed of three South EU economies (Italy, Portugal and Spain) plus Estonia and two Visegrad 5 economies (Slovenia and Czechia). 
Table 3. Technology catching up and falling behind based on ITU indexes for EU25 and its macro-regions 2015-06.

\begin{tabular}{|c|c|c|c|c|c|c|c|c|c|c|c|c|}
\hline & \multicolumn{4}{|c|}{2006} & \multicolumn{4}{|c|}{2015} & \multicolumn{3}{|c|}{ 2006-2015 } & \multirow[b]{2}{*}{$\begin{array}{c}\% \text { change } \\
\text { in ITU }\end{array}$} \\
\hline & INDEX A & INDEX B & INDEX C & ITU & INDEX A & INDEX B & INDEX C & ITU & $\begin{array}{c}\% \text { change } \\
\text { in INDEX A }\end{array}$ & $\begin{array}{c}\% \text { change } \\
\text { in INDEX B }\end{array}$ & $\begin{array}{l}\% \text { change } \\
\text { in INDEX C }\end{array}$ & \\
\hline BEL & 38.0 & 61.5 & 19.0 & 99.5 & 45.4 & 64.9 & 12.9 & 110.3 & 19.7 & 5.4 & -31.8 & 10.88 \\
\hline NLD & 53.9 & 65.8 & 83.7 & 119.7 & 55.3 & 66.0 & 60.0 & 121.3 & 2.6 & 0.4 & -28.4 & 1.41 \\
\hline GBR & 46.2 & 64.6 & 33.3 & 110.8 & 45.1 & 66.0 & 22.3 & 111.1 & -2.3 & 2.2 & -33.1 & 0.31 \\
\hline DEU & 70.0 & 61.1 & 21.2 & 131.1 & 68.6 & 62.9 & 22.6 & 131.5 & -2.0 & 2.9 & 6.2 & 0.29 \\
\hline FRA & 48.0 & 61.5 & 23.4 & 109.5 & 47.0 & 62.6 & 22.2 & 109.6 & -2.1 & 1.9 & -4.8 & 0.12 \\
\hline IRL & 37.2 & 65.7 & 48.9 & 102.9 & 36.7 & 65.4 & 82.3 & 102.1 & -1.4 & -0.5 & 68.2 & -0.81 \\
\hline DNK & 60.4 & 72.8 & 10.9 & 133.3 & 61.9 & 62.6 & 11.1 & 124.6 & 2.5 & -14.0 & 2.1 & -6.55 \\
\hline AUS & 55.3 & 62.5 & 12.0 & 117.8 & 55.1 & 54.8 & 10.6 & 110.0 & -0.2 & -12.2 & -12.0 & -6.60 \\
\hline FIN & 68.9 & 80.2 & 17.7 & 149.2 & 63.7 & 69.0 & 12.3 & 132.7 & -7.6 & -14.0 & -30.5 & -11.06 \\
\hline SWE & 70.1 & 79.8 & 20.6 & 149.9 & 67.7 & 65.4 & 20.9 & 133.1 & -3.4 & -18.1 & 1.1 & -11.23 \\
\hline EU North & & & & & & & & & 0.6 & -4.6 & -6.3 & -2.32 \\
\hline PRT & 24.2 & 38.0 & 6.8 & 62.1 & 34.4 & 45.1 & 6.2 & 79.4 & 42.2 & 18.7 & -8.8 & 27.89 \\
\hline ITA & 37.9 & 39.1 & 15.8 & 77.1 & 35.1 & 34.2 & 12.1 & 69.3 & -7.4 & -12.6 & -23.0 & -10.00 \\
\hline ESP & 38.2 & 45.4 & 14.9 & 83.6 & 26.3 & 42.3 & 12.4 & 68.6 & -31.1 & -7.0 & -16.6 & -18.01 \\
\hline GRC & 16.8 & 40.6 & 2.5 & 57.4 & 12.4 & 30.9 & 2.9 & 43.3 & -26.3 & -23.9 & 17.1 & -24.61 \\
\hline EU South & & & & & & & & & -5.6 & -6.2 & -7.8 & -6.18 \\
\hline SVN & 35.0 & 41.4 & 8.6 & 76.4 & 33.7 & 38.7 & 11.0 & 72.4 & -3.9 & -6.4 & 27.5 & -5.26 \\
\hline POL & 12.2 & 33.4 & 9.4 & 45.6 & 11.8 & 31.4 & 9.9 & 43.2 & -2.9 & -6.2 & 5.4 & -5.34 \\
\hline CZE & 36.4 & 52.3 & 11.2 & 88.7 & 32.0 & 44.1 & 13.1 & 76.1 & -12.0 & -15.7 & 17.1 & -14.20 \\
\hline SVK & 15.0 & 44.8 & 11.2 & 59.7 & 15.6 & 34.7 & 13.6 & 50.3 & 4.3 & -22.5 & 21.0 & -15.80 \\
\hline HUN & 24.4 & 39.8 & 23.5 & 64.2 & 13.2 & 35.7 & 15.5 & 48.8 & -45.9 & -10.4 & -34.1 & -23.88 \\
\hline VIS-5 & & & & & & & & & -12.1 & -12.3 & 7.4 & -12.90 \\
\hline LAT & 14.7 & 29.4 & 3.2 & 44.1 & 17.0 & 32.3 & 5.8 & 49.3 & 16.1 & 9.8 & 84.1 & 11.89 \\
\hline LTU & 13.7 & 39.6 & 5.0 & 53.3 & 19.8 & 39.7 & 6.2 & 59.5 & 44.1 & 0.4 & 24.3 & 11.65 \\
\hline EST & 26.0 & 47.5 & 9.1 & 73.5 & 31.0 & 43.9 & 4.6 & 74.9 & 19.1 & -7.4 & -49.7 & 1.96 \\
\hline BLT-3 & & & & & & & & & 26.4 & 0.9 & 19.5 & 8.50 \\
\hline ROU & 9.3 & 33.8 & 5.2 & 43.2 & 10.2 & 26.5 & 7.8 & 36.6 & 8.9 & -21.8 & 49.2 & -15.12 \\
\hline BGR & 13.1 & 29.6 & 6.7 & 42.8 & 11.6 & 21.8 & 4.7 & 33.4 & -11.9 & -26.4 & -29.3 & -21.93 \\
\hline HRV & 12.7 & 35.4 & 6.7 & 48.1 & 8.5 & 26.7 & 6.1 & 35.2 & -33.2 & -24.6 & -9.8 & -26.88 \\
\hline SEE-3 & & & & & & & & & -12.1 & -24.3 & 3.4 & -21.31 \\
\hline EU Periphery & & & & & & & & & -0.8 & -10.4 & 5.6 & -7.97 \\
\hline
\end{tabular}


The ITU, as a framework that tries to capture the broader scale and scope of technology upgrading, shows that there has been a decline in the index in all macro regions except Baltic 3. Moreover, the decline has been the biggest at the EU periphery $(-7.97 \%)$ compared to the EU North (-2.32\%). Within the periphery, the decline has been the greatest in SEE-3 ($21.3 \%)$, followed by the Visegrad $5(-12.9 \%)$ and EU South (-6.2\%). We can observe an opening of the technological capability gap between the EU North and the periphery, with the exception of the Baltics. The homogeneity of results based on ITU is quite high as we can observe identical trends in all periphery countries (except Portugal) and a polarisation of the EU North of those countries which have improved their position based on ITU and those which have declined in relative terms.

Index A and Index B components of ITU, as well as Index C, show changes in varied directions by macro region and by country. Romania, for instance, a country with the highest growth rate, performs well in Index A and Index C. This suggests favourable conditions for production capability and knowledge interactions with foreign partners to compensate structural changes in the country. In the Baltics region, we can observe a positive link between the three upgrading indexes and the growth rates of these countries. Although Estonia, Latvia and Lithuania have minimal expenditures on R\&D, their concerted efforts in production capabilities (particularly Lithuania) and knowledge interactions with the global environment (in the case of Latvia) seem to have resulted in the high growth rates they have achieved. In the sections below, we explore these factors in detail in the context of macro-regions and CEE countries.

\section{Analysis of technology upgrading in the context of catching up and growth}

In this section, we focus on policy-relevant insights that stem from technology upgrading metrics. First, we explore the relative positions of the EU macro-regions on all four indexes of technology upgrading.

As expected, the EU periphery trails behind the EU North on both indexes of technology upgrading. Regarding the intensity of TU (Index A), the periphery is at $40 \%$ of the EU North level, and regarding the scope of TU (Index B) it is at 60\% of the EU North level (see Figure 5 ). This better performance of scope relative to intensity of technology upgrading is a common feature of all periphery macro-regions and, as we will go on to discuss, this is due to their comparatively better infrastructure as well as structural change. In fact, the poorer the macro-region, the better its performance in terms of scope compared to intensity of technology upgrading. Regarding the index of technology and knowledge exchange, the periphery also trails behind the EU North, with only the Visegrad 5 countries having a much more developed technology and knowledge exchange. This is in tune with other results which show the existence of a Central European manufacturing cluster linking the EU industrial core to the Visegrad 5 economies (IMF, 2013). 
Figure 5. EU25 macro-regions in indexes of technology upgrading in 2015.

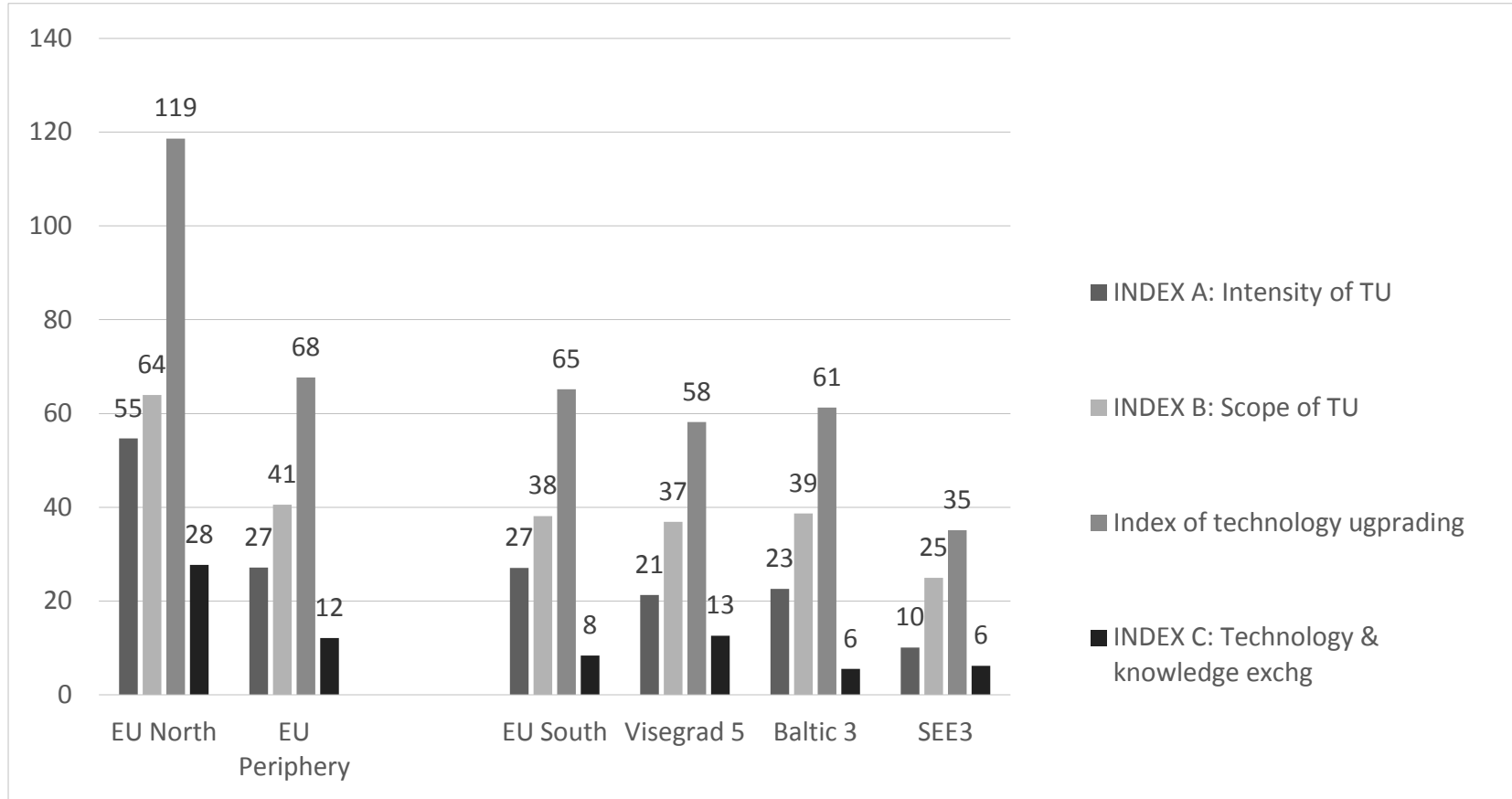

Note: Based on country averages.

What lies behind the significant gap between the EU North and periphery in intensity, and behind the lesser gap in the scope of technology upgrading potential? Figure 6 shows that the significantly lower intensity of technology upgrading is strongly driven by big differences in technological capabilities (TC). In index A, these are patenting-related activities which in periphery countries rank particularly low on a world scale. In TC the gap is one third, in R\&D it is slightly above $50 \%$ while in production capability it is less that $30 \%$. The smaller gap in the scope of technology upgrading potential is due to the better position of the periphery in terms of infrastructure and structural change, with a gap to the EU North of around $30 \%$. However, the biggest gap here is with respect to firm capabilities, which are less than $50 \%$ those of the EU North (44.9\%).

This pattern of technological and firm capabilities being by far the lowest components of ITU is present in all EU periphery macro-regions. Also, all macro-regions perform relatively better regarding production capabilities, infrastructure and structural change when compared to the EU North as a reference. This pattern of relative underperformance in technology capabilities and firm capabilities, and overperformance in infrastructure and structural change, holds true in relation to GNI pc gaps when compared to the EU North in all macro-regions. Therefore, we can take this to be a stable structural feature of the EU periphery, with important policy implications. 
Figure 6. Levels of EU25 macro-regions in different components of technology upgrading potential in $\mathbf{2 0 1 5}$

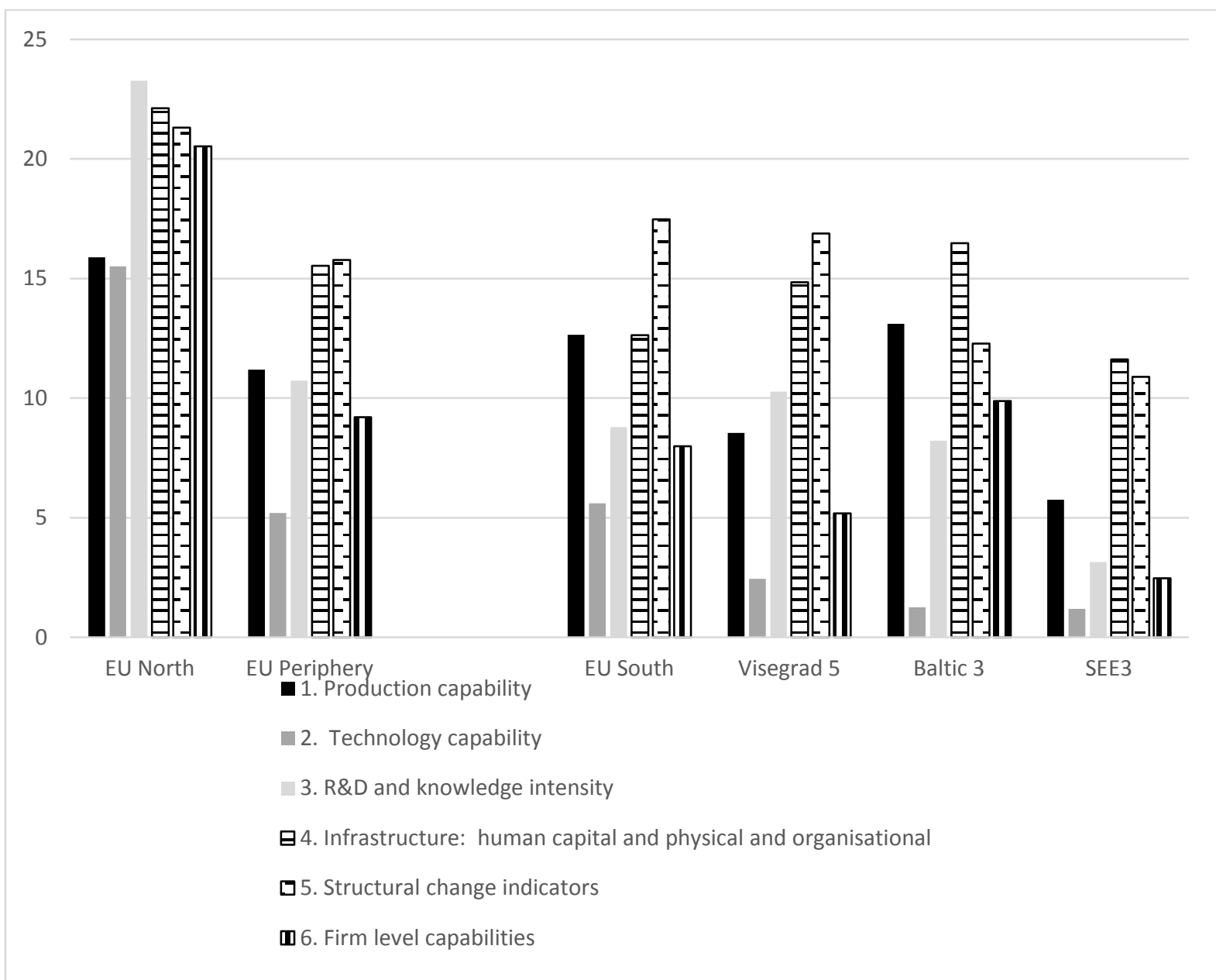

4. Infrastructure: human capital, physical and organisational

A crucial question is what has led to the increased technological gap within the EU25? Figure 7 shows changes in different components of ITU by macro-region, and Figure 8 by country. 
Figure 7. Changes in components of ITU 2006-15 in EU25 macro-regions (\%)

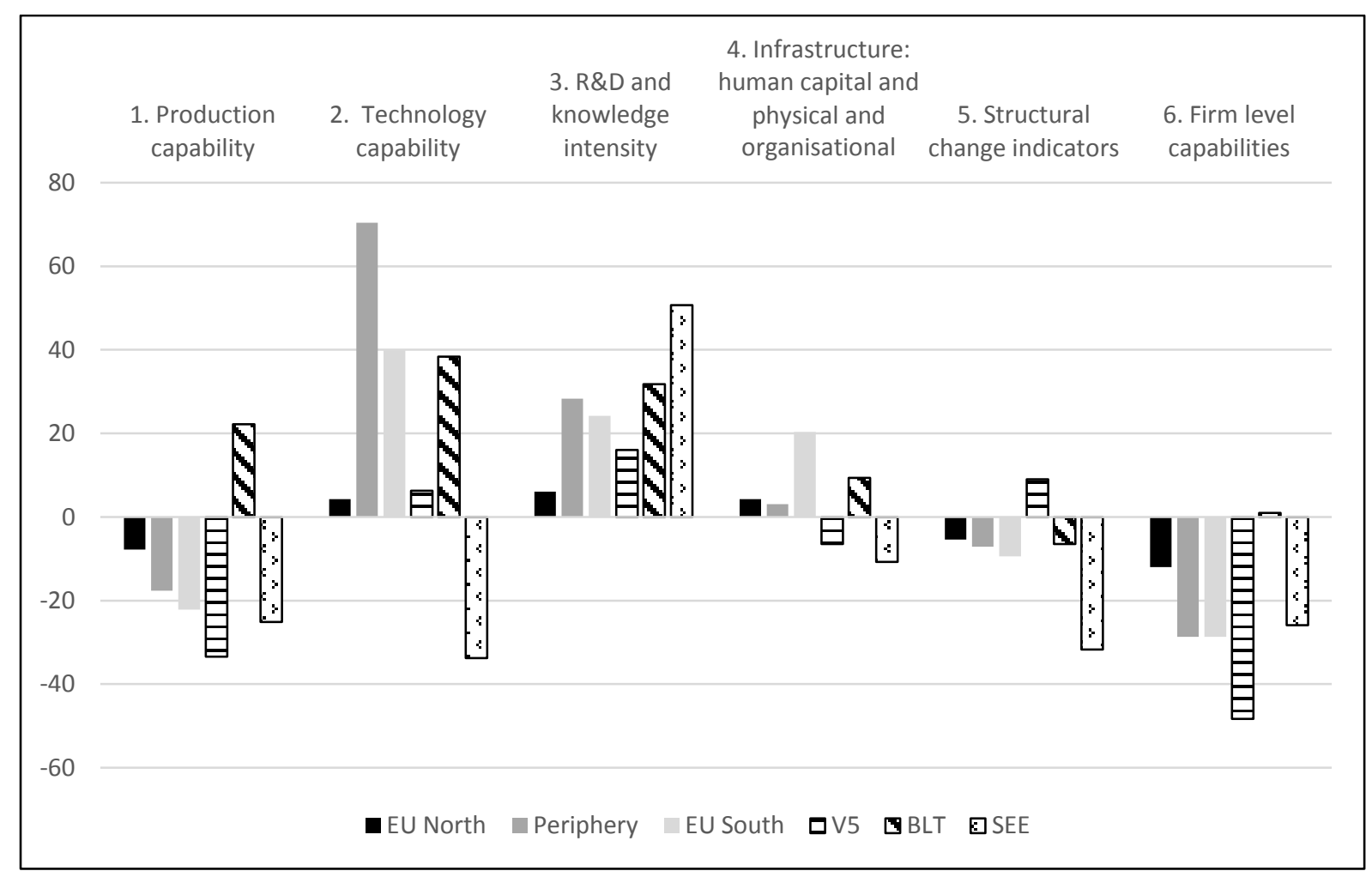

Note: For the Baltic states, for presentation purposes, we have reduced the change in the technological capability component for Lithuania from $324 \%$ to $100 \%$, due to the huge increase in the number of patents from a very low base level.

Figure 7 shows the overall improvement in the EU25 regarding R\&D and knowledge intensity in all macro-regions as well as improvements in terms of technology capability in all but the SEE-3 region. For instance, R\&D and knowledge intensity and technology capability are dimensions of technology-based growth which are well captured by the European Innovation Scoreboard (EIS) and thus there is a high compatibility of changes in this respect between ITU and EIS. Regarding infrastructure, there is no clear trend within macro-regions, where two out of six macro-regions (Visegrad 5 and SEE3) have fallen behind while in others the infrastructure has improved. However, in all other components, EU macro-regions have fallen behind, with the exception of the Baltics in production capability and to some extent firm capabilities, and the Visegrad 5 regarding structural change. However, the overall trend that emerges from individual components of ITU is improved $R \& D$ and technology capability and smaller, varied changes in infrastructure, but a major lag 
in firm capabilities and production capabilities, as well as lesser deterioration regarding structural change.

These macro-regional trends roughly hold across individual countries. Thus, broad patterns of improved R\&D and technological capability accompanied by a relative decline regarding production and firm capabilities can be observed across the majority of the EU25 economies. In production capability and structural change components 17 economies, and in firm capabilities 21 out of 25 economies, have fallen behind; meanwhile in R\&D 19 economies, in infrastructure 16 economies, and in technology capability 12 out of 25 economies, have improved.

Index C, namely, the Index of technology and knowledge exchange (ITKE) is a separate index which does not add cumulatively to the index of technology upgrading. The forms and types of technology transfer are quite varied and statistical indicators can only very poorly capture the accumulated capabilities which cross national borders. This is less of an issue with disembodied knowledge transfer, as depicted through payments and receipts for technological knowledge, except for several countries where transfer pricing plays an important role as a mechanism of tax evasion (for example, Ireland, the Netherlands and Hungary within the EU25). Capturing accumulated knowledge through export figures is a challenging issue; in future, trade in value-added figures could be a great help in this respect, although their availability is still limited. FDI flows are very remotely related to knowledge flows, and supporting evidence is very inconclusive and context dependent. A simple relationship between levels of productivity and our composite index of technology and knowledge exchange shows a very weak relationship with EU25. This reflects the ambiguity of this index, from which it is difficult to discern whether knowledge inflows operate as a substitute or complement to their own technology activities.

Figure 8 below excludes Ireland and the Netherlands, whose inclusion would give a very distorted picture. While within indexes of technology upgrading we can observe, on average, a strong correlation with productivity levels, in the case of Index C the relationship reflects much more the different strategies of involvement in the global economy. The EU North is no longer as homogenous as it used to be similar to the EU periphery where the Baltics, SEE and EU South (Portugal and Greece) are mixed at the low end of the index. In the middle of the regression line, we find both the EU North, EU South (Italy and Spain) and all Visegrad 5 economies. The most striking are the very similar Index values of the Visegrad 5 and North/South EU group. Given their lower levels of productivity, the Visegrad 5 have an exceptionally high level of technology and knowledge exchange. We would argue that this reflects the Central European Manufacturing cluster which includes the EU manufacturing core (Germany, Austria, Netherlands, France, Belgium) and the Visegrad 5 economies which have become an integral part of this cluster (see IMF, 2013). 
Figure 8. Labour productivity (GNI per employee) and Index of technology and knowledge exchange (ITKE) relationship (2015) (without Ireland and the Netherlands)

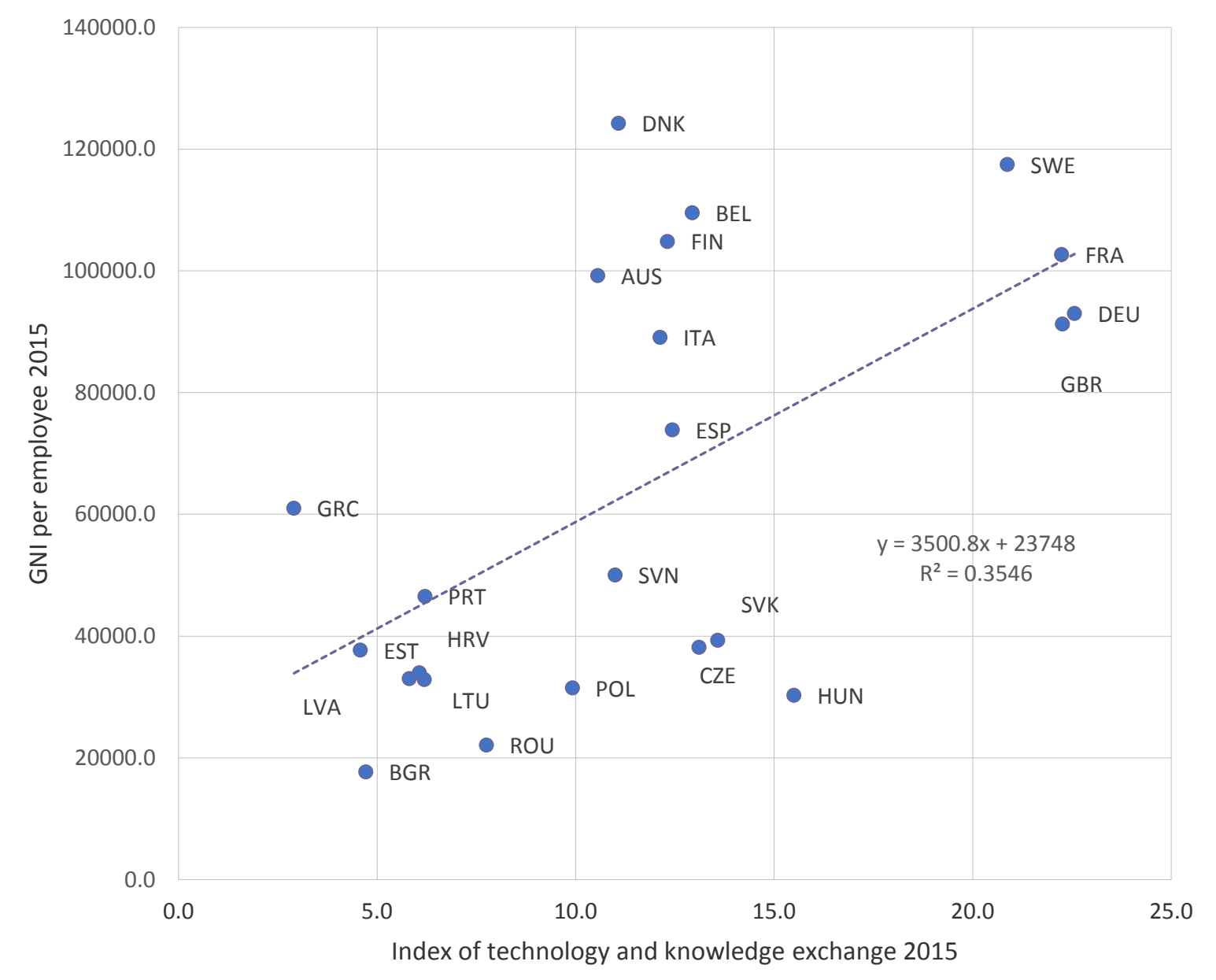

It seems that the 2008 crisis did not erode this cluster; instead the cluster has expanded to include a few other periphery economies (Figure 9 and 10). While overall, EU North and EU South links with the global economy have declined, this has not been the case to such an extent with the CEECs, where the decline in links for all three CEE regions has been minimal. 
Figure 9. Index C - Index of technology and knowledge exchange (ITKE) by EU25 macro region, 2006, 2015 and change 2015-06 (without Ireland and the Netherlands).

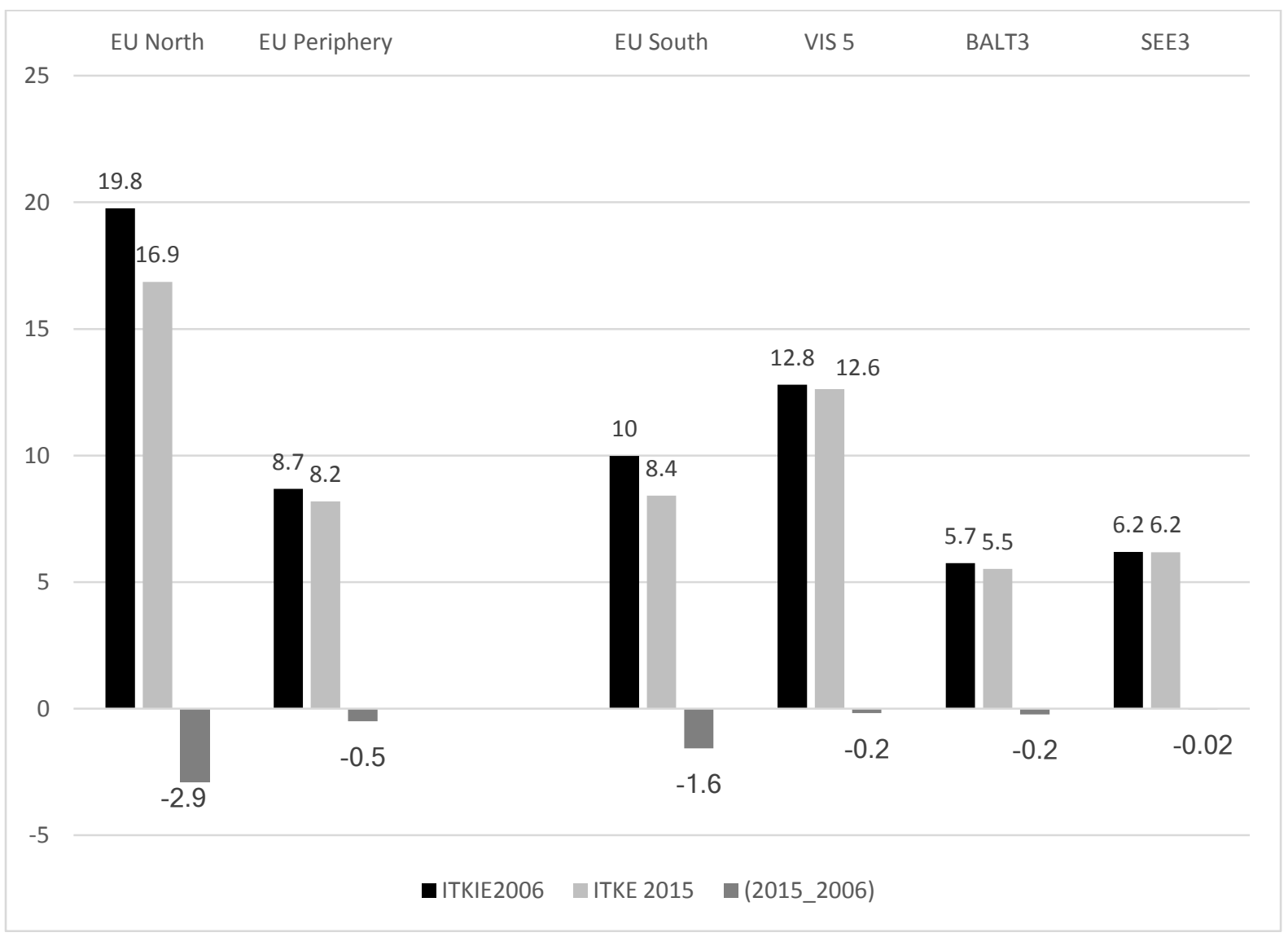

However, the picture of individual countries shows that there have been some interesting changes in this period (see Figure 10). The Visegrad 5 intensity of links has actually declined due entirely to Hungary. Although all the Visegrad countries (except for Slovenia) experienced a decrease in FDI flows, Hungary experienced a dramatic fall in both FDI inflows and outflows over the period 2006-2015. Slovenia, on the other hand, not only continued to attract FDI inflows, but also considerably increased its royalty receipts. The intensity of links of Romania and Latvia (not shown on graph due to the huge increase but from a very low base) considerably improved over the period. This is due to an increase in the share of high-tech exports in their total exports compared to other countries in their respective regions, and to transfer pricing in their technology balance of payments. The decrease in Estonia's intensity of links is due to a decrease in FDI inflows and outflows, the sharpest among the three Baltic countries.

Within the EU North, German links have increased mainly due to the increase in royalty receipts, while links for all other EU North economies have declined. The main factor that offsets Belgium, Austria and UK's position in terms of intensity of links is the significant decrease in FDI inflows and outflows, compared to Germany. Finland suffered from the steepest decline in the share of high-tech exports in total exports. The only exception in this respect is Ireland (not shown on the graph due to the huge increase) whose links increased 
by $68 \%$ at a level of 82.3 on Index $C$ due to continuing FDI flows, the important role of technology balance of payments and transfer pricing, and the increasing share of high-tech exports in total exports. Links for the Netherlands declined by $28 \%$ but, given the important role of technology balance of payments and transfer-pricing, it is difficult to discern financial from technological (knowledge) components. Links for the EU South declined overall despite significant increases in Greece, though from very low base.

Overall, with respect to the technology and knowledge exchanges of EU 25, we can observe a polarisation between, on the one hand, Germany and the Visegrad economies, which increasingly includes Romania, and on the other hand, the rest of the EU, which shows a decline in intensity as well as technology and knowledge exchanges.

Figure 10. Index C - Index of technology and knowledge exchange (ITKE) by country in 2015 and changes in the index between 2006 and 2015 (\%).

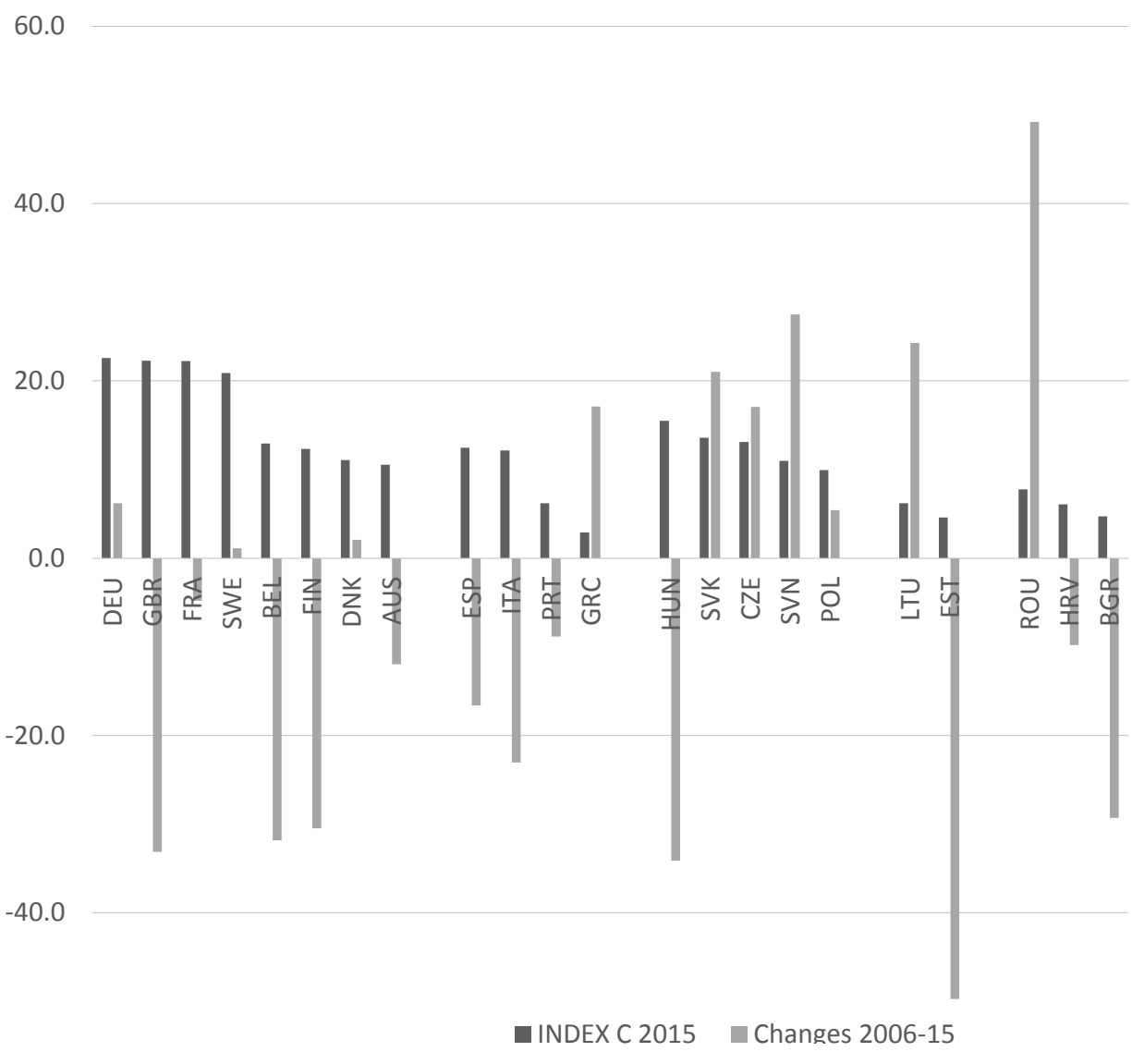

$-60.0$

Note: The figure does not include Ireland, the Netherlands and Latvia whose index in 2015 was $82.3,60.0$ and 5.8 respectively and whose changes between 2006 and 20015 were $+68 \%,-28 \%$ and $+84 \%$ respectively.

\section{Conclusions and policy issues}

In this chapter, we have measured the innovation and technology activities of the EU25 within the technological upgrading framework. The analytical value of this composite indicator is relevant as it focuses metrics on the dimensions of technology upgrading that matter for the growth of the broadly defined EU catching-up economies. 
We have argued that the RTDI issues of relevance for catching up cannot be understood or conceptualised only within the R\&D based growth model. The CEE countries are predominantly technology users; the pattern of their technology upgrading is different. With this motivation in mind, we have created a composite indicator of innovation capacity and performance of the CEECs, as well as of the EU25, which is meaningful from the perspective of countries lagging behind the world technology frontier. This is an important new modification given the strong need to refocus the innovation policies of the CEECs on issues of greater relevance for their current technology and industry upgrading.

We have conceptualised technology upgrading as a three-dimensional process, consisting of: dimension 1 (the vertical axis) reflecting the intensity of technology upgrading as depicted by different types of innovation activities; dimension 2 (the horizontal axis) depicting the spread or breadth of technology such as the diversity of technological knowledge, types of supporting infrastructure and structure of firms which carry out technology upgrading; and dimension 3 (the diagonal axis) describing knowledge inflows into the economy through a variety of forms such as trade, FDI and knowledge exchange.

Three conclusions stem from the Index of Technology Upgrading components which seem to have major relevance for policy making.

Firstly, we can observe a decline in most of the EU25 economies of their production capabilities despite, on average, significant improvements in R\&D and technology capability. This is important, as production capability is much more closely related to export and trade than R\&D and technology capability, particularly in countries lagging behind the technology frontier. This suggests that the EU has serious weaknesses in converting its R\&D and technological knowledge into production capabilities. The Index of technology knowledge exchange confirms this by showing a decline in the majority of the EU25, except in economies that belong to the Central European manufacturing cluster.

Secondly, the ITU components show improvements in infrastructure and structural changes in most of the EU economies, but an overall relative decline in firm capabilities. This is probably a reflection of the declining role of large EU firms in the global economy and the very weak firm capabilities in the EU periphery. Again, this shows the limitations of current EU supply oriented RDI policies which continue to reinforce the so-called European paradox.

Thirdly, increased knowledge interaction between 2006 and 2015 has been confined to the German-led Central European manufacturing cluster (Slovenia, Slovakia, Czechia, Poland, Hungary and recently, it seems, Romania). This fits well with evidence on trade within the EU showing that this area is the one which has increased its relative share in intra-EU trade (see WIIW, 2016). Overall, stagnant technology and knowledge exchange for the majority of the EU25, especially the EU South and parts of SEE, suggest that foreign direct investment (FDI), subcontracting and global value chain (GVC) policy is not a factor of regional advantage. It seems that the EU RDI policy operates as a substitute for technology and knowledge exchange rather than as a complement to it. 
Within this context, we can observe a polarisation of the CEE into countries which are members of the German-led central European cluster and other countries which do not benefit from access to European and global value chains. Given their peripheral and semiperipheral positions, future growth prospects of the CEE countries are strongly dependent not only on their trade, FDI, GVC and other knowledge flows with the EU core, but also on their accumulation of production, technology and R\&D capabilities. EU membership has improved their standing regarding technology and R\&D capabilities, as well as regarding technology infrastructure. However, their key weakness are weak firm-level capabilities which are a key ingredient for converting R\&D and technological knowledge into production capabilities. Improvement in R\&D and technology capabilities has been unrelated to their production and firm capabilities which has de facto opened up new structural gaps in their innovation systems. EU structural funds represent a unique 'window of opportunity' to close these gaps by promoting the coupling of investments in enterprise R\&D and labour skills with technology upgrading in design, engineering, management and production capabilities. However, there is emerging evidence that this challenge is not yet well understood, as demonstrated in inconsistent and 'zig-zag' policies (Breznitz and Ornston, 2018).

All in all, our analysis depicts a much more worrying picture regarding the prospects of the EU as a convergence machine. From the ITU perspective, we can observe an increased technology gap rather than technology convergence. It seems that this increasing technology gap is not driven by R\&D policies, but by the disconnection between EU R\&D and other policies such as FDI and GVC policies, between technology and production capability related policies and improvements, and ultimately by weak firm organisational capabilities. In other words, the EU has reached limits where only R\&D based policy can operate as a driver of technology convergence It is necessary to re-examine other policy areas relating to industrial policy, financial systems and corporate governance. It seems that the ultimate weakness for the technology gap lies in non-technological factors such as poor corporate governance and weak capital markets which do not favour growth and the emergence of large technology-based firms which could commercialize and implement acquired R\&D and technological knowledge, and function as network organisers. At the EU level, current policies that promote the expansion of R\&D via structural funds only serve to deepen the R\&D-implementation gap. In order to close this gap, these policies should be reexamined to favour the implementation of innovations at the regional level.

\section{References}

Aghion, P., Harmgart, H. and Weisshaar, N. 2010. Fostering growth in CEE countries: a countrytailored approach to growth policy, EBRD Working paper N0.118, available at https://www.ebrd.com/downloads/research/economics/workingpapers/wp0118.pdf

Aghion, P., Akcigit, U. and Howitt, P. 2013. What Do We Learn From Schumpeterian Growth Theory? NBER Working Paper Series No 18824, February 
Alam A, Casero, P.A., Khan, F., Udomsaph, C. 2008. Unleashing Prosperity: Productivity Growth in Eastern Europe and the Former Soviet Union. World Bank, Washington, DC

Labaye, L., Sjatil, P.E., Bogdan, W., Novak, J., Mischke, J., Fruk, M. and lonut, U., 2013, A new dawn: Reigniting growth in Central and Eastern Europe', McKinsey Global Institute, December 2013, available at: https://www.mckinsey.com/featured-insights/europe/a-new-dawn-reigniting-growthin-central-and-eastern-europe.

Breznitz, D. and Ornston, D. (2017) EU financing and innovation in Poland, EBRD Working Paper No. 198, January

Dobrinsky, R., Hesse, D. and Traeger, R. 2006. Understanding the long-term growth performance of the East European and CIS Economies. Discussion paper series, No 2006-1, United Nations.

Ernst, D. 1998. Catching-up crisis and industrial upgrading: evolutionary aspects of technological learning in Korea's electronics industry, Asia Pacific Journal of Management, 15(2), 247-283.

Freudenberg, M., 2003. Composite indicators of country performance: a critical assessment. STI Working Paper 2003/16, OECD.

Gereffi, G. 1999. International trade and industrial upgrading in the apparel commodity chain, Journal of International Economics, 48(1), 37-70.

IMF 2013. German-Central European Supply Chain-Cluster Report : Staff Report, First Background Note, Second Background Note, Third Background Note, International Monetary Fund European Dept., Country Report No. 13/263, August 2013

Lee, K. 2013. Schumpeterian Analysis of Economic Catch-up, Knowledge, Path-creation and the Middle-Income Trap, Cambridge: Cambridge University Press.

Lin, J. Y. 2015. The Washington Consensus revisited: a new structural economics perspective Journal of Economic Policy Reform, Volume 18, Issue 2, pp. 96-113

Lucas, R.E. 1988. On the Mechanics of Economic Development, Journal of Monetary Economics, Vol. 22 , pp. 3-42.

OECD 2003. The Sources of Economic Growth in OECD Countries, OECD, Paris.

Romer, P.M. 1990. Endogenous Technological Change, Journal of Political Economy, Vol. 98, No. 5, pp. 71-102

Radosevic, S., and Yoruk, E. 2015. A New Metrics of Technology Upgrading: The Central And East European Countries in a Comparative Perspective, GRINCOH Working Paper, No. 3.04, Available at http://www.grincoh.eu/media/serie 3 knowledge innovation technolog/grincoh wp 3.04 radosevic yoruk.pdf

Radosevic, S., and Yoruk, E. 2016a. A new metrics of technology upgrading: The Central and Eastern European Countries in a comparative perspective. UCL Centre for Comparative Studies of Emerging Economies (CCSEE) Working Paper, 2016/2. Available at https://www.ucl.ac.uk/ssees/comparative-studies-emerging-economies/working-papers 
Radosevic, S., and Yoruk, E. 2016b. Why do we need theory and metrics of technology upgrading? Asian J. Tech. Innov. 24 (Sup 1), 8-32. https://doi.org/10.1080/19761597.

2016.1207415.

Radosevic, S., and Yoruk, E. 2018. Technology Upgrading of Middle Income Economies: A New Approach and Result'. Technological Forecasting and Social Change. 129, 56-75.

WIIW 2016. The Evolving Composition of Intra-EU Trade, WIIW Research Reports, No. 414, November 2016

\section{Appendix: Methodology for index construction}

The individual indicators in Table 2 are used to construct the three technology upgrading indexes Index A, Index B and Index C by using composite index methodology.

A typical composite indicator will take the form (Freudenberg, 2003: 7):

$$
I=\sum_{i=1}^{n} w_{i} \mathrm{X}_{i}
$$

where

I: Composite index,

$\mathrm{X}_{i}$ : Normalised variable,

$w_{i}$ : Weight of the $\mathrm{X}_{i}, \quad \sum_{i=1}^{n} w_{i}=1$ and $0 \leq w \leq 1$

$i: 1, \ldots, \mathrm{n}$.

Equation (2) shows explicitly the normalisation method (Min-Max) used:

(2) $I_{c}=\sum_{j=1}^{J} \sum_{m=1}^{M} w_{j m}\left\{\left(\mathrm{X}_{j m c}-\mathrm{X}_{j m}^{\min }\right) \mid\left(\mathrm{X}_{j m}^{\max }-\mathrm{X}_{j m}^{\min }\right)\right\}$

where $\mathrm{c}$ indicates country, $\mathrm{j}$ and $\mathrm{m}$ are indicator and component subscripts and $\min$ and $\max$ denote the minimum and maximum values of each indicator across countries.

\section{Explanations for Composite Index Measures}

\section{Technology upgrading intensity index (INDEX A)}

The type and intensity of technology upgrading depends on the production and technology capabilities as well as the skills of enterprises and the population, investments and outputs in new knowledge creation and generation, and the extent of R\&D activities. These are 
essential to technology upgrading, as without them product and process innovations cannot be developed.

Index A is composed of three components: Production capability (Index 1), technology capability (Index 2) and R\&D and knowledge intensity (Index 3). Accordingly:

Index $A=$ Index $1+\operatorname{Index} 2+$ Index 3

Production capability (Index 1) aims to capture the rate of activities and output in relation to production activity. It is composed of three indicators:

1. ISO9001 certificates (per million inhabitants), taken from the International Organization for Standardization (ISO);values between 2006 and 2015 are used in the analysis.

2. Trademark applications, resident (per million inhabitants), taken from World Intellectual Property Organization (WIPO);values between 2006 and 2015 are used in the analysis.

3. The extent of staff training, taken from World Economic Forum Global Competitiveness Report (WEF GCR) Question Q.5.08; values between 2006 and 2015 are used in the analysis. It is based on the question 'In your country, to what extent do companies invest in training and employee development? [1=not at all; 7=to a great extent]).

Technology capability (Index 2 ) is built on measuring technology generation capabilities, mainly in terms of patents. It is composed of four indicators drawn from the World Intellectual Property Organization (WIPO), and values between 2006 and 2015 are used in the analysis:

4. Patent applications, resident, to the national office (per million inhabitants)

5. Patent applications to USPTO (per million inhabitants)

6. Patent applications to EPO (per million inhabitants)

7. Industrial design count, residents (per million inhabitants)

R\&D and knowledge and intensity (Index 3 ) aims to capture the knowledge developed by investments in R\&D as well as the influence of capabilities embodied in people, i.e. R\&D personnel, scientists and their publication outputs. It draws on eight indicators. For each one, values between 2006 and 2015 are used in the analysis.

8. Business Enterprise Sector R\&D expenditures (\% of GDP), taken from Eurostat.

9. Research and development expenditure (\% of GDP), taken from the World Bank.

10. Researchers in R\&D (per million inhabitants), taken from the World Bank.

11. Technicians in R\&D (per million inhabitants), taken from the World Bank.

12. Scientific and technical journal articles (per million inhabitants), taken from the World Bank

13. Science citations (per million inhabitants), taken from SJR - Scimago Journal and Country Rank (https://www.scimagojr.com/). 
14. The quality of scientific research institutions, taken from the WEFGCR Question 12.02. It is based on the question: How would you assess the quality of scientific research institutions in your country? [ 1 = very poor; 7 = the best in their field internationally]

15. University - industry collaboration in R\&D is taken from WEFGCR Question 12.04. It is based on the question: To what extent do business and universities collaborate on research and development (R\&D) in your country? [1 = do not collaborate at all; $7=$ collaborate extensively]

\section{Technology upgrading breadth index (INDEX B)}

The breadth of technology upgrading lies in structural features and changes in these structural features. Structural features are based on human capital, physical capital and organisational issues.

Index B is composed of three components: Human capital, physical and organizational infrastructure (Index 4), structural change (Index 5) and firm-level capabilities (Index 6). Accordingly:

Index $B=$ Index $4+$ Index $5+$ Index 6

Human capital, physical and organizational infrastructure (Index 4 ) is built by measuring the influence of capabilities embodied in people throughout the wider population in terms of education, the response to skills demand, the extent people exploit available infrastructural technologies and the level of fixed investment. Accordingly, it is composed of six manifest indicators:

1. Average years of schooling for ages $25+$, taken from the Barro-Lee database. The values for each year between 2006 and 2015 are extrapolated using the data from 1950 to 2010.

2. The quality of maths and science educational institutions, taken from WEFGCR Question 5.04 for the years 2006-2015. It is based on the question: How would you assess the quality of maths and science education in your country's schools? [ 1 = poor; 7 = excellent - among the best in the world]

3. The availability of specialized research and training services, taken from WEFGCR Question 5.07 for the years 2006-2015. It is based on the question: In your country, to what extent are high-quality, specialized training services available? [1 = not available; 7 = widely available $]$

4. The availability of scientists and engineers, taken from WEFGCR Question 12.06 for the year2 2006-2015. It is based on the question: To what extent are scientists and engineers available in your country? [ $1=$ not at all; $7=$ widely available]

5. Fixed broadband Internet subscribers (per 100 people), taken from the World Bank for the years 2006-2015. 
6. Gross Fixed Capital Formation as \% of GDP, taken from the World Bank for the years 2006-2015.

Structural change (Index 5) aims to capture, over time, changes in technology capability, demand structure and level of available technologies. It comprises six indicators. The first two indicators use patent data from WIPO to calculate the Herfindahl-Hirschman Index. By this, we aim to assess the level of diversification by technology field/class in the patenting structure of countries. The formula for the Herfindahl-Hirschman index calculation is given below:

$$
H=\sum_{i=1}^{n} s_{i}^{2}
$$

Where $s_{i}$ is the share of patents of a country in a specific technology field. The index is calculated for each of the countries based on the WIPO technology classification (see Appendix $\mathrm{E}$ for a list of 35 technology fields). The same method is applied to calculate the Herfindahl-Hirschman index for national patent applications (Indicator 22), applications to EPO (Indicator 23) and applications to USPTO (Indicator 24).

7. Herfindahl-Hirschman Index for total national patent applications.

8. Herfindahl-Hirschman Index for patent applications to EPO

9. Buyer sophistication, taken from WEFGCR Question 6.16 for the years 20062015. It is based on the question: In your country, how do buyers make purchasing decisions? [ 1 = based solely on the lowest price; 7 = based on a sophisticated analysis of performance attributes]

10. Change in buyer sophistication (annual \% change in Q. 6.16 between 2006-2015)

11. Availability of state-of-the-art technologies, taken from WEFGCR Question 9.01 for the years 2006-2015. It is based on the question: To what extent are the latest technologies available in your country? [ $1=$ not available; $7=$ widely available]

12. Change in the availability of the latest technologies (annual \% change in Q.9.01 between 2006-2015)

Firm-level capabilities (Index 6) has two manifest indicators:

13. Number of firms in Forbes 2000 (per million inhabitants) for the years 20062015.

14. Firm-level technology absorption, taken from WEFGCR Question 9.02 for the years 2006-2015. It is based on the question: To what extent do businesses in your country absorb new technology? [1 = not at all; 7 = aggressively absorb]

3. Index of technology and knowledge exchange (ITKE) 
This index aims to capture the influence of the global interactions of countries by which knowledge flows take place. We assess the impact of such interactions as complementary to technology upgrading. The index comprises seven manifest indicators:

1. Technology balance of payments (receipts) in US\$, taken from the World Bank for the years 2006-2015.

2. Licencing receipts as \% of GDP, taken from the World Bank for the years 2006-2015.

3. Technology balance of payments (payments) in US\$, taken from the World Bank for the years 2006-2015.

4. Licencing payments as \% of GDP, taken from the World Bank for the years 20062015.

5. The share of exports of complex industries in total exports (SITCRev3 5 71-79 87 88). Data for this indicator have been extracted from UNComtrade for the years 20062015. We calculated the share of exports in the total exports of each country, particularly in SITC Rev.3 sectors: 5 - Chemicals and related products, n.e.s.; 71 to 75 Machinery (Power generating machines, special industrial machinery, metalworking machinery, general industrial machinery, n.e.s, office machines); 76 telecommunications equipment; 78-79 transport equipment (road vehicles, other transport equipment); 87-88 electrical and optical (scientific equipment, n..e.s., photo apparatus n.e.s., clocks).

6. Foreign direct investment, net outflows (\% of GDP), taken from the World Bank for the years 2006-2015.

7. Foreign direct investment, net inflows (\% of GDP), taken from the World Bank for the years 2006-2015. 